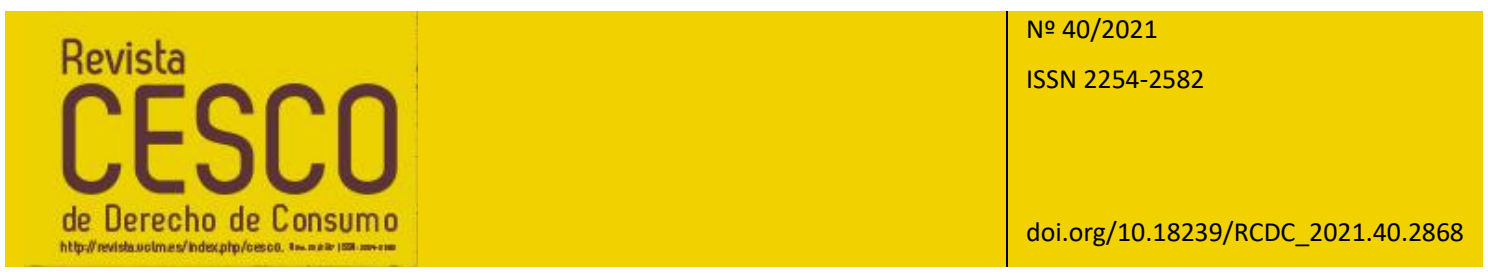

\title{
CUESTIONES POLÉMICAS EN LOS PROCEDIMIENTOS MONITORIOS RELATIVOS A LA RECLAMACIÓN DE SALDO DE TARJETAS REVOLVING
}

\author{
David Burrero del Castillo \\ Abogado en ejercicio, Colegiado nº 15.184 del ICAS
}

\begin{abstract}
Resumen: En el presente trabajo me centraré en el estudio, desde la posición procesal del deudor demandado, de algunas de las cuestiones más polémicas que tienen lugar en los procedimientos monitorios y en los procedimientos declarativos subsiguientes relativos a la reclamación de saldo de tarjetas de crédito revolving: los documentos requeridos para la admisión a trámite del procedimiento monitorio, el control de oficio de cláusulas abusivas, la omisión de pronunciamiento sobre la excepción de nulidad causada por la usura, la sujeción de las cláusulas contractuales al control de transparencia y los efectos restitutorios de la declaración de nulidad contractual.
\end{abstract}

Palabras clave: Procedimiento monitorio; tarjetas de crédito rotativo; intereses usurarios; deudor cautivo; cláusulas abusivas; control de transparencia; nulidad contractual; incongruencia omisiva; excepción reconvencional.

Tittle: SOME CONTROVERSIAL ASPECTS ABOUT THE MONITORIO PROCEDURE RELATING TO THE CLAIM FOR REVOLVING CREDIT CARD DEBTS

Abstract: Throughout this paper I will focus, from the defendant debtor's point of view, on the analysis of some of the most controversial issues that take place in the monitorio procedure and the subsequent declarative procedures, in which revolving credit card debts are claimed: the documents required for admission to processing of the monitorio procedure, ex officio control over the unfair terms, the omission of a pronouncement on the counterclaim exception relating to contractual invalidity caused by the usury, the subjection of the contractual clauses to the transparency control, as well as the restorative effects of the declaration of contractual nullity.

Key words: Monitorio procedure; revolving credit cards; usurious interest rate; captive debtor; unfair terms; transparency control; contractual invalidity; incongruity; counterclaim exception. 
SUMARIO. 1. Petición inicial monitoria que no adjunta contrato de tarjeta de crédito y/o extracto de movimientos. 2 . Control de oficio del carácter abusivo de las cláusulas contractuales y de los intereses usurarios. 3. Omisión de pronunciamiento en la sentencia sobre la excepción de nulidad contractual por intereses usurarios. 4. Sujeción a doble control de transparencia de las cláusulas del contrato de tarjeta de crédito. 5. Problemas prácticos al aplicar los efectos restitutorios de la declaración de nulidad contractual por usura. 6. Conclusiones. 7. Referencias y citas.

\section{Petición inicial monitoria que no adjunta contrato de tarjeta de crédito y/o extracto de movimientos}

Resulta relativamente frecuente en la práctica procesal que la entidad financiera, 0 empresa cesionaria con legitimación activa para reclamar el saldo, no aporte junto a la petición inicial monitoria la documental probatoria de la existencia de la relación contractual y de las disposiciones de capital efectuadas con la tarjeta, limitándose a adjuntar un certificado de saldo que indica el principal, intereses y otras partidas adeudadas. A propósito de esta práctica, se cuestiona si resulta procedente admitir a trámite el monitorio cuando el demandante aporta sólo un certificado de saldo confeccionado unilateralmente por el acreedor. De la lectura literal del artículo 812 de la Ley $1 / 2000$ de 7 de enero de Enjuiciamiento Civil (BOE no 7 de 08/01/2000) se extrae que un certificado de saldo confeccionado unilateralmente por el acreedor en principio encuentra encaje entre los documentos previstos en la norma, sin embargo es bastante cuestionable que este documento por sí solo, no acompañado del contrato y de los extractos de operaciones donde se reflejan las disposiciones y cobros, pueda constituir un principio de prueba de modo que la deuda tenga buena apariencia jurídica, tal como exige el artículo 815.1 LEC para la admisión a trámite y requerimiento de pago. Por lo demás, es obvio que la admisión a trámite no prejuzga la suficiencia o insuficiencia probatoria de esa documental en un juicio declarativo, en caso de que el deudor formule oposición al monitorio, ello atendiendo al principio de carga de la prueba del artículo 217 LEC.

La cuestión relativa a si un certificado de saldo, por sí solo y no acompañado del contrato y los extractos de operaciones, constituye un principio de prueba del derecho del peticionario, no es pacífica en la jurisprudencia. Citaré a modo de ejemplo algunas resoluciones. En los Acuerdos adoptados en Junta Sectorial de Magistrados de las Secciones Civiles Generales y de la Sección Mercantil de la Audiencia Provincial de Madrid, celebrada el 19 de septiembre de 2019, se establece que la falta de aportación inicial de documentos esenciales para determinar la cuantía, liquidez y exigibilidad de la deuda, considerando como tales el contrato y el extracto de operaciones, constituye causa de no admisión de demandas en procedimientos monitorios donde se reclama el saldo de tarjetas de crédito. Por su parte, la Sección Sexta de la Audiencia Provincial de Sevilla tiene declarado en Auto no 273/2020 de 8 de octubre (AAP SE 571:2020), que no es posible establecer de forma inicial que la deuda sea vencida, líquida y exigible cuando la deuda reclamada ha sido fijada 
unilateralmente por la reclamante, se aporta una copia incompleta del contrato y un extracto contable que no refleja los conceptos integrantes de la deuda, por lo que confirma la resolución de instancia, que acordó inadmitir la petición inicial monitoria por no acompañar, al menos, el extracto de la cuenta con relación de los movimientos y especificación de las partidas debidas. En la misma línea, el Auto no 91/2021 de 17 de marzo de la Sección Segunda de la Audiencia Provincial de Sevilla (AAP SE 88:2021), que considera que tratándose de reclamaciones de saldo de tarjeta de crédito, la petición inicial monitoria debe adjuntar tanto el contrato como los extractos de las operaciones realizadas con cargo a la tarjeta remitidos al deudor, así como los pagos y cargos realizados que permitan al deudor enjuiciar la corrección de la cantidad reclamada y, en su caso, impugnarla. En la misma línea, la Sección 16a de la Audiencia Provincial de Barcelona en Auto no 127/2021 de 20 de mayo (AAP B 3633:2021), considera insuficiente la aportación del contrato y un certificado de saldo para constituir principio de prueba y exige, adicionalmente, extractos de movimientos. Coincide con las anteriores la Sección Quinta de la Audiencia Provincial de Las Palmas, que en Auto no 67/2020 de 21 de febrero (AAP GC 51:2020), considera insuficiente la aportación del contrato y un certificado de saldo, exigiendo adicionalmente los extractos detallados de movimientos en que se expresan las operaciones en cada período, detallando concepto, comercio en que se utilizó la tarjeta o cajero de extracción de efectivo, importe de cada transacción, intereses generados y saldo final del período, al considerar que sólo a través de dichos extractos puede conocer el deudor el origen de la deuda reclamada. Sin embargo, en sentido contrario encontramos el Auto no 140/2018 de 27 de abril de la Sección Segunda de la Audiencia Provincial de Girona (AAP GI 229:2018), donde considera que deberá admitirse la petición inicial monitoria cuando a ella se acompañe copia del contrato y certificado de saldo, aunque no se aporte extracto alguno de movimientos de la cuenta asociada a la tarjeta de crédito. También a favor de un criterio flexible de admisión, la Sección Tercera de la Audiencia Provincial de Valladolid, en Auto no 29/2021 de 22 de febrero (AAP VA 199:2021), que tiene declarado que la certificación de saldo emitida por la acreedora y el contrato del que dimana la deuda justifican indiciariamente la existencia del crédito y por tanto, cuando son aportados con la petición inicial, procede la admisión a trámite del monitorio.

\section{Control de oficio del carácter abusivo de las cláusulas contractuales y de los intereses usurarios}

En sede de procedimiento monitorio, el artículo 815.4 LEC contempla un ineludible control judicial de oficio de posibles cláusulas abusivas insertas en el contrato que constituyan el fundamento de la petición monitoria o que determinen la cantidad 
exigible ${ }^{1}$, el cual debe efectuarse con carácter previo a la admisión a trámite y al requerimiento de pago al deudor, dando audiencia por plazo de 5 días a las partes, transcurrido el cual el juez resolverá mediante auto acordando, bien la improcedencia de la pretensión o bien la continuación del procedimiento sin aplicación de las cláusulas consideradas abusivas, siendo dicho auto apelable en todo caso.

En el supuesto de la reclamación de saldo de una tarjeta de crédito, nos encontramos ante una supuesta deuda de origen contractual, siendo el acreedor un empresario o profesional y el deudor un consumidor o usuario, en la medida que obtuviera la financiación con un propósito ajeno a actividades comerciales, empresariales o profesionales ${ }^{2}$. En tal caso, el control judicial de oficio es preceptivo. Pues bien, del mismo modo que el artículo 815.4 LEC no deja lugar a dudas respecto a que debe realizarse el control de oficio con carácter previo a la admisión a trámite del monitorio, no encontramos en la LEC una expresa previsión de que el control de oficio deba llevarse a cabo en cualquier momento del proceso declarativo, ya sea verbal u ordinario, subsiguiente al monitorio en caso de oposición del deudor. Pese a la falta de previsión expresa en la LEC, es claro que el órgano judicial debe controlar de oficio la posible abusividad de las cláusulas contractuales en cualquier fase del procedimiento, siempre que éste no haya finalizado, disponga de los elementos de hecho y de Derecho necesarios para efectuar dicho control y no se haya emitido pronunciamiento sobre la cláusula en cuestión con anterioridad mediante resolución firme con fuerza de cosa juzgada. El meritado control de oficio conforme a estos criterios viene impuesto por la jurisprudencia del Tribunal de Justicia de la Unión Europea, en interpretación de la Directiva 93/13/CEE del Consejo, de 5 de abril de 1993, sobre las cláusulas abusivas en los contratos celebrados con consumidores (DOCE núm. 95, de 21 de abril de 1993, páginas 29 a 34) ${ }^{3}$ y así lo tiene declarado también el Tribunal Constitucional en múltiples sentencias ${ }^{4}$.

Respecto a todas aquellas cláusulas que constituyan el fundamento de la pretensión o determinen la cantidad exigible y no hayan sido objeto de control de oficio en el trámite indicado, es claro que el momento procesal oportuno para que la parte alegue su carácter abusivo es la oposición al monitorio y, en su caso, la contestación a la demanda del ordinario subsiguiente. Sin embargo, más controvertida es la cuestión relativa a si el auto que se dicte tiene fuerza de cosa juzgada respecto a aquellas

\footnotetext{
${ }^{1}$ El examen de oficio debe respetar los límites del objeto del litigio, tal como declara la STJUE de 11 de marzo de 2020 (Sala Tercera), asunto C-511/17 (ECLI:EU:C:2020:188), comentada por AGÜERO ORTIZ, A.: EI TJUE declara que los jueces solo han de examinar de oficio la abusividad de las cláusulas vinculadas al objeto del litigio. Publicaciones Jurídicas Centro de Estudios de Consumo. Madrid, 2020. Disponible en: http://centrodeestudiosdeconsumo.com/images/EI TJUE declara que los jueces solo han de examin ar de oficio la abusividad de las clausulas vinculadas al objeto del litigio.pdf

2 Artículo 3 del Real Decreto Legislativo 1/2007 de 16 de noviembre, por el que se aprueba el texto refundido de la Ley General para la Defensa de los Consumidores y Usuarios y otras leyes complementarias (BOE n० 287 de 30 de noviembre).

3 STJUE de 14 de junio de 2012 (Sala Primera), asunto Banco Español de Crédito, C-618/10 (ECLI:EU:C:2012:349); STJUE de 26 de enero de 2017 (Sala Primera), asunto Banco Primus, S.A. y Jesús Gutiérrez García, C-421/14 (ECLI:EU:C:2017:60).

${ }^{4}$ Sentencia del Tribunal Constitucional (Pleno) no 31/2019 de 28 de febrero (ECLI:ES:TC:2019:31), STC de la Sala Segunda no 140/2020 de 6 de octubre (ECLI:ES:TC:2020:140), STC de la Sala Primera nº 24/2021 de 15 de febrero (ECLI:ES:TC:2021:24).
} 
cláusulas que sí hayan sido objeto de expreso control de oficio en esta fase, ya que la LEC guarda silencio sobre este concreto extremo; en mi opinión, la solución más lógica es que el auto tenga fuerza de cosa juzgada, una vez sea firme, respecto a las cláusulas que hayan sido objeto de expreso control, con el fin de evitar pronunciamientos contradictorios ${ }^{5}$. No ofrece dudas la redacción del artículo 815.4 respecto a que, en todo caso, el auto que resuelva sobre las posibles cláusulas abusivas vinculadas al objeto litigioso, acordando la improcedencia de la pretensión o la inaplicación de dichas cláusulas, debe ir precedido de un trámite de audiencia a las partes, ya que de lo contrario se quebraría el principio de contradicción y el impedimento de formular oposición alegando la abusividad, provocado por la fuerza de cosa juzgada del auto, generaría indefensión. Por otro lado, nada obsta a alegar en la oposición al monitorio el carácter abusivo de aquellas cláusulas que no hayan sido objeto de expreso control de oficio mediante el indicado auto.

Si el órgano judicial, simple y llanamente, prescinde del trámite de control de oficio en el momento previo a la admisión a trámite del monitorio, hecho que no es infrecuente en la práctica, requiere de pago al deudor y éste no paga ni formula oposición, el Letrado de la Administración de Justicia dictará decreto poniendo fin al monitorio y dicha resolución será ejecutable (art. 816.1 LEC). Al tratarse de un título judicial, no podrá el deudor oponerse a la ejecución del mismo por cláusulas abusivas, como sí podría hacerlo tratándose de un título no judicial como una escritura pública o una póliza de contrato mercantil, pero cabe preguntarse si el hecho de haber prescindido del preceptivo control de oficio sobre el posible carácter abusivo de las cláusulas puede motivar una nulidad de actuaciones; en mi opinión se da en tal caso el supuesto de nulidad de pleno derecho del artículo $2253^{\circ}$ LEC, infracción de las normas esenciales del procedimiento que produce indefensión, la cual podrá hacerse valer conforme al incidente excepcional de nulidad de actuaciones del art. 228 LEC $^{6}$.

Otro supuesto que puede darse es que el juzgador no efectúe el control de oficio pero el deudor formule oposición al monitorio, alegando la nulidad contractual por intereses usurarios pero no la nulidad de concretas cláusulas contractuales sobre la base de su carácter abusivo. En mi opinión, si tal fuera el caso, no plantea dudas que el deber de control de oficio sobre el carácter abusivo de las cláusulas, siempre que guarden vinculación con el objeto litigioso, se extiende al juicio verbal u ordinario subsiguiente al monitorio, $y$ en tanto dicho procedimiento declarativo no finalice mediante sentencia el juzgador deberá realizar dicho control, incluso cuando el demandado haya alegado la abusividad de manera extemporánea (esto es con

\footnotetext{
${ }^{5}$ En esa línea, MORENO GARCÍA, L.: Las cláusulas abusivas: tratamiento sustantivo y procesal. Tirant Lo Blanch. Valencia, 2019. Página 525 y siguientes.

${ }^{6}$ En ese sentido, la STC (Sala Primera) núm. 102/2021 de 10 de mayo (ECLI:ES:TC:2021:102) ha declarado una vez más que "el derecho a la tutela judicial efectiva de los consumidores resulta vulnerado si, en el proceso de ejecución hipotecaria, el juzgado no se pronuncia sobre la abusividad de una cláusula, incluso cuando fuera planteada de forma extemporánea, fuera del plazo de oposición a la ejecución, mediante un incidente de nulidad de actuaciones". Sobre ello escribe AGÜERO ORTIZ, A., en: No realizar el control de abusividad vulnera el derecho a la tutela judicial efectiva. Publicaciones Jurídicas del Centro de Estudios de Consumo. Madrid, 16/06/2021. Disponible en: http://centrodeestudiosdeconsumo.com/images/No realizar el control de abusividad vulnera el derec ho a la tutela judicial efectiva.pdf
} 
posterioridad a la oposición al monitorio o, en su caso, a la contestación a la demanda del ordinario).

Por lo que respecta a la usura, según reiterada jurisprudencia del Tribunal Supremo ${ }^{7}$ la nulidad absoluta es apreciable de oficio, aunque no haya sido alegada o se haya alegado con deficiencias de carácter formal, siempre y cuando la sinalagmática contractual se refiera a pactos manifiestamente ilegales, contrarios a la moral o al orden público. Siendo así, debería existir consenso en torno a que la usura constituye en nuestro ordenamiento jurídico una práctica manifiestamente ilegal, inmoral y lesiva del orden público, encuadrable por tanto en los indicados supuestos de nulidad a efectos de su apreciación de oficio. No obstante, uno de los problemas que suscita la apreciación de usura es, precisamente, la ausencia de una regla clara y terminante que permita determinar cuándo un interés remuneratorio es usurario, a diferencia de lo que sucede en otros Ordenamientos jurídicos, y por ello la cuestión relativa a su posible apreciación de oficio es objeto de controversia entre las audiencias provinciales.

En ese sentido, por citar algunos ejemplos, la Sección Sexta de la Audiencia Provincial de Sevilla tiene declarado en sentencia no 516/2020 de 21 de diciembre (SAP SE 1383:2020), que es posible controlar de oficio la posible naturaleza usuraria de un préstamo derivado de un contrato de tarjeta de crédito; a su vez, la Sección Cuarta de la Audiencia Provincial de Barcelona, en sentencia no 255/2021 de 21 de abril (SAP B 4212:2021), también considera que la usura es apreciable de oficio; a favor también de la posible apreciación de oficio de la usura, la Sección Tercera de la Audiencia Provincial de Badajoz en sentencia no 197/2020 de 26 de noviembre (SAP BA 1434:2020); sin embargo, la Sección Octava de la Audiencia Provincial de Valencia, en sentencia no 142/2021 de 31 de marzo (SAP 1338:2021), sostiene que no procede apreciar de oficio el carácter usurario de los intereses remuneratorios y que, yendo un paso más allá, ni siquiera cabe oponer la nulidad por ese motivo por la vía de la excepción en la oposición a una demanda monitoria (particular que trataremos en el siguiente epígrafe), sino que necesariamente debe formularse mediante acción o reconvención.

\footnotetext{
7 Entre otras, la Sentencia del Tribunal Supremo (Sala de lo Civil) no 508/1996 de 20 de junio (TOL1.659.451) admite "...la apreciación de oficio para los actos nulos de pleno derecho, pero no ante negocios no infractores de un precepto claro y terminante y mucho menos respecto a aquellos actos $y$ contratos cuya apariencia jurídica correcta merece el debido respeto, mientras no se impugnen en forma eficaz $y$, consecuentemente, mediante el ejercicio de las oportunas acciones, respetándose los principios de contradicción procesal y tutela efectiva constitucional, para que la otra parte pudiera defenderse y alegar sus razones opositoras.

La doctrina permisiva de referencia ha quedado suficientemente concretada por esta Sala, en su condición de excepcional y restrictiva en cuanto suple la inactividad de los litigantes, en este caso entidad actora y no opera como excusa de la denunciada incongruencia, pues ha de evitarse la proliferación de nulidades inconsistentes, no oportunamente aducidas, y conformando debate procesal, al entrar su ejercicio en el ámbito de la autonomía de la voluntad e iniciativa e interés de la parte a la que le puede asistir el derecho."
} 


\section{Omisión de pronunciamiento en la sentencia sobre la excepción de nulidad contractual por intereses usurarios}

En este epígrafe es objeto de estudio el supuesto de falta de pronunciamiento sobre el carácter usurario de los intereses en la sentencia dictada en el proceso declarativo, ya sea ordinario o verbal, subsiguiente al monitorio cuando el deudor ha formulado en tiempo y forma la correspondiente excepción material o de fondo relativa a dicho extremo. No trataré en este trabajo los criterios fijados en la jurisprudencia reciente del Tribunal Supremo, STS no 628/2015 de 25 de noviembre (STS 4810:2015) y STS no 149/2020 de 4 de marzo (STS 600:2020), ambas de la Sala de lo Civil, para interpretar el artículo 1 de la Ley de 23 de julio de 1908 sobre nulidad de los contratos de préstamos usurarios (Gaceta de Madrid no 206 de 24/07/1908), en particular cuándo el interés estipulado es notablemente superior al normal del dinero $y$ desproporcionado con las circunstancias del caso. Aquí me centraré exclusivamente en el deber que tiene el juzgador de resolver en la correspondiente sentencia, ya sea del juicio ordinario o del verbal subsiguiente al monitorio, sobre la alegación de nulidad contractual basada en la usura, hecha valer mediante excepción en la oposición al monitorio y, en su caso, en la contestación a la demanda del ordinario.

Para situar adecuadamente la cuestión procesal, hay que recordar brevemente lo establecido en el art. 818 LEC a propósito de la oposición del deudor. Una vez que el deudor formula oposición, el litigio se resolverá definitivamente en el juicio declarativo que corresponda, teniendo la sentencia que se dicte fuerza de cosa juzgada. Cuando la cuantía de la pretensión no exceda de la propia del juicio verbal, el LAJ dictará decreto dando por terminado el monitorio y acordando seguir la tramitación conforme a lo previsto para este tipo de juicio, dará traslado de la oposición al actor y éste podrá impugnarla. Mientras que si la cuantía de la reclamación excede de la propia del verbal, el peticionario deberá presentar demanda conforme al procedimiento ordinario, el LAJ dictará decreto poniendo fin al monitorio y dará traslado de la misma al demandado, quien tendrá el plazo previsto en el procedimiento ordinario para formular contestación.

Si bien en ocasiones encontramos sentencias que no aducen fundamento alguno para omitir el mencionado pronunciamiento, un argumento comúnmente empleado es que los intereses no son objeto de la reclamación formulada por la actora, sino únicamente el principal. Mientras que en el juicio ordinario subsiguiente al monitorio, la contestación a la demanda es el escrito rector de la defensa, en el juicio verbal desempeña esa función el escrito de oposición al monitorio; en ambos casos, cuando se aduce por la vía de la excepción material la nulidad del contrato por intereses usurarios, la sentencia que se dicte en el correspondiente declarativo deberá pronunciarse necesariamente sobre dicho extremo. Como arriba se ha dicho, algunos órganos judiciales consideran que cuando el demandante reclama sólo el principal, los intereses no forman parte del objeto litigioso y por tanto no puede enjuiciarse su nulidad si se alega por la vía de la excepción, es decir sostienen que para pronunciarse sobre la nulidad del contrato por intereses usurarios, es necesario que 
el demandado formule acción o reconvención. En mi opinión, esta práctica incurre en varias y muy graves infracciones procesales que expondré a continuación.

En primer lugar, de la jurisprudencia del Tribunal Supremo relativa a que la nulidad radical del contrato por intereses usurarios es apreciable de oficio en aquellos supuestos de pactos manifiestamente ilegales, contrarios a la moral o al orden público, como es el caso de la usura. Ya hemos tenido ocasión de tratar el tema con mayor profundidad en el epígrafe anterior.

En segundo lugar, del art. 408.2 LEC, que en sede de juicio ordinario establece expresamente que si el demandado adujere en su defensa la nulidad absoluta del negocio en que se funde la pretensión del actor, la sentencia deberá pronunciarse sobre dicho extremo y tal pronunciamiento tendrá fuerza de cosa juzgada. En mi opinión, la posibilidad de oponer la nulidad absoluta del contrato como excepción prevista en el juicio ordinario es extensible por analogía al juicio verbal, pues aunque el art. 438 LEC no haga referencia a la nulidad sino únicamente a la compensación, es razonable integrar dicha norma con el espíritu del artículo 408 LEC, toda vez que no existen motivos fundados para sostener que el silencio del artículo 438 LEC pueda interpretarse como limitativo de la facultad de oponer la alegación de nulidad, un diferente tratamiento de la figura en el juicio verbal carecería de justificación en el Derecho positivo y sin duda ocasionaría un notorio perjuicio al derecho de defensa del demandado ${ }^{8}$. A propósito de ello tiene declarado el Tribunal Supremo que la nulidad radical del contrato, a diferencia de la nulidad relativa o anulabilidad, puede ser alegada por la vía de la excepción, sin necesidad de formular acción o reconvención ${ }^{9}$, lo que se denomina excepción reconvencional. Entiende la doctrina por excepción reconvencional aquella que, aun introduciendo en el proceso un nuevo objeto de debate que obliga al juzgador a pronunciarse sobre el mismo independientemente de la demanda principal, su función no va más allá de la búsqueda de la simple desestimación de la demanda del actor, de modo que el hecho en cuya virtud se invoca va dirigido exclusivamente a enervar el derecho del demandante. Como su propio nombre indica, la excepción reconvencional tiene una naturaleza híbrida; es una excepción en el sentido de que su formulación pretende únicamente enervar la acción de la demanda obteniendo la absolución, pero es al mismo tiempo reconvencional porque amplía el objeto del litigio. La excepción reconvencional se plantea como cualquier otra excepción sustantiva, sin necesidad de sujetarse a las exigencias formales de la reconvención previstas en el artículo 406 LEC y sin necesidad de que se formule de manera separada del resto de alegaciones de naturaleza defensiva. Ahora bien, huelga decir que si la nulidad se plantea como

\footnotetext{
${ }^{8}$ En esa línea, TAFUR LÓPEZ DE LEMUS, J.: ¿Es necesario formular reconvención en la contestación a la demanda en el juicio verbal si se alega la nulidad de un contrato? (art.408 y 438.3 LEC). Sitio web El Derecho - Lefebvre, 29/05/2018. Disponible en: https://elderecho.com/es-necesario-formularreconvencion-en-la-contestacion-a-la-demanda-en-el-juicio-verbal-si-se-alega-la-nulidad-de-uncontrato-art-408-y-438-3-lec; GARCÍA DE LA ROSA, C.: Las excepciones reconvencionales y su régimen en el juicio verbal. Revista General de Derecho Procesal 35 (2015). Iustel. Madrid, 2015; ARSUAGA CORTÁZAR, J.: Artículo 408.2: Alegación de nulidad del negocio jurídico en que se funda la demanda en Marín Castán, F. (Director), Comentarios a la Ley de Enjuiciamiento Civil. Tirant Lo Blanch. Valencia, 2015. Página 1779 y siguientes.

${ }^{9}$ A modo de ejemplo reciente, la STS, Sala de lo Civil, no 172/2018 de 23 de marzo (STS 1110:2018).
} 
excepción, en caso de ser estimada sólo podrá tener un alcance enervatorio de la acción y conducir a la absolución de la demanda.

En tercer lugar, dicha omisión de pronunciamiento infringe lo establecido en el artículo 218 LEC, relativo a los requisitos de congruencia y exhaustividad de la sentencia. Si el demandado pide la desestimación de la demanda fundada en la nulidad absoluta alegada por la vía de la excepción, el órgano judicial debe pronunciarse necesariamente sobre dicho extremo en la sentencia, tal como establece el comentado artículo 408.2 LEC. Partiendo de la doctrina sentada por la STC no 20/1982 de 5 de mayo (ECLI:ES:TC:1982:20), la congruencia se mide por el ajuste o adecuación entre la parte dispositiva y los términos en que las partes han formulado sus pretensiones y peticiones y cuando la desviación en que consiste la incongruencia es de tal naturaleza que supone una completa modificación de los términos en que se produjo el debate procesal, puede entrañar una vulneración del principio de contradicción y por ende del fundamental derecho de defensa ${ }^{10}$. Según reiterada jurisprudencia del Tribunal Supremo ${ }^{11}$, la congruencia consiste en la necesaria conformidad que ha de existir entre el fallo de la sentencia y las pretensiones deducidas, teniendo en cuenta la petición y la causa de pedir. Descendiendo al supuesto concreto que nos ocupa, la omisión de pronunciamiento sobre una excepción de nulidad contractual constituye incongruencia omisiva y falta de exhaustividad, en la medida que se guarda absoluto silencio sobre elementos fundamentales de las pretensiones ejercitadas, causando indefensión, y no se resuelven las cuestiones litigiosas planteadas. Si bien no resulta exigible una contestación explicita y pormenorizada a todas y cada una de las alegaciones aducidas por las partes para fundamentar sus pretensiones, sí se requiere un pronunciamiento razonado sobre las pretensiones en sí mismas consideradas. En ese sentido, la excepción reconvencional de nulidad absoluta del contrato no es un fundamento jurídico más en que la parte sustenta su pretensión de desestimación de la demanda, sino un hecho determinante y presupuesto lógico de la pretensión absolutoria, por ello siempre que sea planteada en tiempo y forma la sentencia deberá pronunciarse expresamente sobre la misma. A propósito de la cuestión, interesa citar la sentencia no 412/2020 de 5 de noviembre (SAP SE 1068:2020) de la Sección Sexta de la Audiencia Provincial de Sevilla, que aprecia incongruencia omisiva en la sentencia de instancia porque no resuelve sobre la pretensión del demandado de que se declaren usurarios los intereses remuneratorios pactados en el contrato de tarjeta de crédito, con la consecuencia de que los mismos no puedan ser objeto de reclamación y, por tanto, la obligación del deudor quede limitada a la devolución del principal.

A mayor abundamiento, el argumento comúnmente empleado para omitir un pronunciamiento sobre la nulidad contractual por intereses usurarios, relativo a que los intereses no forman parte del objeto litigioso cuando el demandante afirma estar

10 BRUÑÉN BARBERÁ, F.: Artículo 218: Principio de Congruencia en Marín Castán, F. (Director), Comentarios a la Ley de Enjuiciamiento Civil. Tirant Lo Blanch. Valencia, 2015. Página 1016 y siguientes. ${ }^{11}$ STS no 365/2013 de 6 de junio (TOL3.853.518) y STS no 434/2013 de 12 de junio (TOL3.834.289); ambas de la Sala de lo Civil. 
reclamando únicamente el principal, nace de una errónea valoración del saldo presentado por la actora. En la mayoría de reclamaciones de saldo de tarjetas de crédito, el deudor ha pagado elevadas cantidades a cuenta durante varios años, de modo que la partida denominada principal se ha formado a partir del cobro de cuotas mensuales que incluyen, en primer término, intereses, quedando reservada a la amortización del capital sólo la parte residual o restante de la cuota. Así, la nulidad radical del contrato por intereses usurarios conlleva que el acreedor sólo tendrá derecho a la devolución del capital prestado, deduciendo las cantidades pagadas por todos los conceptos (sobre los efectos restitutorios de la nulidad por intereses usurarios se abundará en el epígrafe número cinco). Distinta cuestión será el alcance y efectos de la declaración de nulidad, dependiendo de la posición procesal que ocupen las partes en el litigio. Si tras recalcular el saldo, como consecuencia de la declaración de nulidad, resultara que el deudor ha abonado una cantidad superior al capital dispuesto, pero la nulidad ha sido alegada por la vía de la excepción y no de la reconvención, el demandante no podrá ser condenado a pagar al demandado cantidad alguna, quedando el pronunciamiento de la sentencia limitado a la desestimación de la demanda, ya que no es posible introducir por la vía de la excepción una pretensión distinta de la desestimación o absolución, ello sin perjuicio de la fuerza de cosa juzgada que tendrá la declaración de nulidad y, por tanto, el derecho a instar la restitución en otro procedimiento mediante la acción correspondiente.

\section{Sujeción a doble control de transparencia de las cláusulas del contrato de tarjeta de crédito}

Más allá de la posible aplicación de la Ley de represión de la usura, cuando el interés estipulado sea notablemente superior al normal del dinero y desproporcionado con las circunstancias del caso, según los criterios de la jurisprudencia reciente del Tribunal Supremo al interpretar el artículo 1 de dicha norma en las citadas STS de 25 de noviembre de 2015 y STS de 4 de marzo de 2020, las cláusulas de los contratos de tarjeta de crédito están sujetas, en supuestos de contratación seriada con consumidores y usuarios ${ }^{12}$, a un control de abusividad desde el ámbito del equilibrio objetivo entre los derechos y obligaciones de las partes, cuando no se refieran a la adecuación entre precio y retribución, y en todo caso desde el ámbito de la transparencia, este último con especial intensidad cuando se trate de cláusulas contractuales relativas al precio. Por tanto, el deudor demandado podrá alegar en el escrito de oposición al monitorio y, en su caso, en la contestación a la demanda del subsiguiente procedimiento ordinario, el carácter abusivo por falta de transparencia de las cláusulas contractuales que corresponda.

Descendiendo al sector de contratación que nos ocupa, observamos que entre las particularidades de los créditos rotativos frente al resto de créditos al consumo se encuentra que el límite de crédito se reconstituye con cada abono y, sobre todo, que

12 Ineludible referencia en esta materia a ALFARO ÁGUILA-REAL, J.: Las condiciones generales de la contratación. Civitas. Madrid, 1991. 
no cuentan de inicio con un plazo de amortización determinado, sino que el plazo se va determinando en función del importe, mayor o menor, de las cuotas que periódicamente se abonan a la entidad para devolver el capital del que se ha ido disponiendo. Así, cuanto más elevados sean los intereses remuneratorios y cuanto menor sea el importe de las cuotas con que se devuelve el capital dispuesto, mayor será la amplitud del plazo, que puede llegar a prolongarse de manera indefinida, y mayor será por tanto el coste total del crédito. Pues bien, las cláusulas relativas a los intereses remuneratorios, la capitalización de intereses y comisiones, el límite de crédito disponible, la existencia o no de plazo máximo de amortización predeterminado, las reglas que rigen el pago aplazado, la cuota mensual mínima por la que el deudor puede optar para devolver el capital prestado, etc., están sujetas en todo caso a un control de transparencia, alcanzando dicho control especial intensidad respecto a las cláusulas configuradoras de los intereses, entendidos en el sentido amplio de la retribución obtenida por el prestamista.

Establece el artículo 80.1 TRLGDCU que las condiciones generales incorporadas a contratos con consumidores deberán cumplir los requisitos de concreción, claridad y sencillez en su redacción, con posibilidad de comprensión directa, ser accesibles y legibles, de forma que permita al consumidor el conocimiento previo a la celebración del contrato sobre su contenido. A su vez, el artículo 82.1 LGDCU dispone que "se considerarán cláusulas abusivas todas aquellas estipulaciones no negociadas individualmente y todas aquellas prácticas no consentidas expresamente que, en contra de las exigencias de la buena fe causen, en perjuicio del consumidor y usuario, un desequilibrio importante de los derechos y obligaciones de las partes que se deriven del contrato".

A estas alturas, los contornos del control de abusividad desde el ámbito de la transparencia se encuentran bastante definidos por la jurisprudencia del TJUE ${ }^{13}$ y por la jurisprudencia del Tribunal Supremo ${ }^{14}$. Así pues, en la jurisprudencia del Tribunal Supremo se establece un doble control de transparencia, el primero en el plano de la incorporación o inclusión, que resulta extensible a todas las condiciones generales del contrato, y el segundo en el plano de la comprensibilidad material, de especial intensidad, aplicable a los elementos esenciales del contrato, tales como el precio o retribución. El control de transparencia queda caracterizado en la citada STS de 8 de septiembre de 2014 como "un control de legalidad en orden a comprobar, primordialmente, que la cláusula contractual predispuesta refiera directamente la comprensibilidad real, que no formal, de los aspectos básicos del contrato en el marco de la reglamentación predispuesta, de forma que el consumidor y usuario conozca y comprenda las consecuencias jurídicas que, de acuerdo con el producto o servicio ofertado, resulten a su cargo, tanto respecto de la onerosidad o sacrificio patrimonial que realmente supone para el consumidor el contrato celebrado, como de la posición

\footnotetext{
13 STJUE de 30 de abril de 2014 (Sala Cuarta), asunto Kásler, C-26/13 (ECLI:EU:C:2014:282); STJUE de 3 de septiembre de 2015 (Sala Cuarta), asunto Costea, C-110/14 (ECLI:EU:C:2015:538); STJUE de 20 de septiembre de 2017 (Sala Segunda), caso Andriciuc y otros, C-186/16 (ECLI:EU:C:2017:703).

${ }^{14}$ STS no 406/2012 de 18 de junio (TOL2.652.597); STS no 464/2014 de 8 de septiembre (TOL4.529.142); STS no 643/2017 de 24 de noviembre (TS 4092:2017); todas de la Sala de lo Civil.
} 
jurídica que realmente asume en los aspectos básicos que se deriven del objeto y de la ejecución del contrato". Dicho control de legalidad trasciende el paradigma del contrato por negociación y por tanto el plano derivado de los vicios del consentimiento, de modo que no tiene por objeto enjuiciar la validez del consentimiento otorgado sino el cumplimiento del comentado deber de transparencia en la reglamentación predispuesta. El control de transparencia forma parte del control de abusividad y no queda reducido a un contraste interpretativo acerca de la claridad gramatical, sino que requiere un propio enjuiciamiento interno de la reglamentación predispuesta a efectos de contrastar la inclusión de criterios comprensibles en orden a que el consumidor pueda evaluar las consecuencias económicas y jurídicas que se derivan a su cargo de la relación contractual ofertada ${ }^{15}$. La comprensibilidad material no debe medirse conforme a parámetros subjetivos sobre el grado de comprensión de un consumidor en concreto atendiendo a su nivel de formación, sino de acuerdo a un parámetro abstracto de comprensibilidad referenciado en la posición del consumidor medio, que por definición carece de conocimientos financieros especializados ${ }^{16}$. Por su parte, la ya citada STS de 24 de noviembre de 2017 declaró que no hay una lista exhaustiva ni cerrada de circunstancias a tener en cuenta con exclusión de cualquier otra para determinar si una cláusula supera el control de transparencia: "no existen medios tasados para obtener el resultado de que un consumidor quede perfectamente informado, por el contrario el perfecto conocimiento de una cláusula, de su trascendencia y de su incidencia en la ejecución del contrato, a fin de que el consumidor pueda adoptar su decisión económica después de haber sido informado cumplidamente, es un resultado insustituible, aunque susceptible de ser alcanzado por pluralidad de medios".

La información que el prestamista debe proporcionar al consumidor, tanto con carácter previo a la celebración del contrato como en el documento contractual, se encuentra definida, respectivamente, en los artículos 10 y 16 de la Ley $16 / 2011$ de 24 de junio de contratos de crédito al consumo (BOE no 151 de 25/06/2011). Incumbe al predisponente la obligación de especificar de manera clara y concisa, entre otros aspectos: la duración del contrato de crédito; el importe total del crédito y las condiciones de disposición del mismo; la tasa anual equivalente y el importe total adeudado por el consumidor, calculados en el momento de la suscripción del

\footnotetext{
15 A propósito del control de transparencia en la doctrina, imprescindible lectura de ORDUÑA MORENO, J.; SÁNCHEZ MARTÍN, C.; GUILLÉN CATALÁN, R.: Control de transparencia y contratación bancaria: régimen jurídico y doctrina jurisprudencial aplicable. Tirant Lo Blanch. Valencia, 2016.

${ }_{16}$ Véase Voto Particular de los Magistrados Orduña Moreno y Arroyo Fiestas a la STS, Sala de lo Civil, no 669/2017 de 14 de diciembre (STS 4308:2017), relativa a la cláusula IRPH de los préstamos hipotecarios, donde cita a propósito del parámetro abstracto de comprensibilidad la STJUE de 3 de septiembre de 2015; posteriormente, en el caso Gómez del Moral Guasch contra Bankia, relativo a la cláusula IRPH de un contrato de préstamo con garantía hipotecaria, la STJUE de 3 de marzo de 2020 (Gran Sala), asunto C125/18 (ECLI:EU:C:2020:138), declara en su párrafo 56 que "la Directiva 93/13, y en particular sus artículos 4, apartado 2, y 5, debe interpretarse en el sentido de que, para cumplir con la exigencia de transparencia de una cláusula contractual que fija un tipo de interés variable en un contrato de préstamo hipotecario, dicha cláusula no solo debe ser comprensible en un plano formal y gramatical, sino también permitir que el consumidor medio, normalmente informado y razonablemente atento y perspicaz, esté en condiciones de comprender el funcionamiento concreto del modo de cálculo del referido tipo de interés y de valorar así, basándose en criterios precisos y comprensibles, las consecuencias económicas, potencialmente significativas, de dicha cláusula sobre sus obligaciones financieras."
} 
contrato de crédito y mencionando todas las hipótesis utilizadas para su cálculo; importe, número y periodicidad de los pagos que ha de efectuar el consumidor y el orden de imputación de los pagos a los distintos saldos pendientes.

No pasamos por alto la reciente aprobación de la Orden ETD/699/2020, de 24 de julio, de regulación del crédito revolvente y por la que se modifica la Orden ECO/697/2004, de 11 de marzo, sobre la Central de Información de Riesgos, la Orden $\mathrm{EHA} / 1718 / 2010$, de 11 de junio, de regulación y control de la publicidad de los servicios y productos bancarios y la Orden EHA/2899/2011, de 28 de octubre, de transparencia y protección del cliente de servicios bancarios (BOE de 27 de julio de 2020). Esta norma ha modificado la Orden EHA/2899/2011 de 28 de octubre, de transparencia y protección del cliente de servicios bancarios para introducir, entre otros aspectos, una letra e) en el apartado 2 del artículo 18, por la que se incorporan reglas específicas de evaluación de solvencia en la concesión de créditos revolving ${ }^{17}$, y una información precontractual, adicional a la información normalizada europea, que la entidad debe proporcionar al consumidor. El nuevo artículo 33 ter de la Orden de 28/10/2011 establece que deberá suministrarse a aquellos clientes personas físicas para los que el contrato prevea la posibilidad de obtener un crédito al consumo con interés de duración indefinida o definida prorrogable de manera automática, en que el capital dispuesto no se satisface en su totalidad al final del período de liquidación pactado (lo que la norma denomina crédito revolving en el ámbito de aplicación del nuevo artículo 33 bis), la siguiente información precontractual: a) mención clara de la modalidad de pago revolving; b) en su caso, la capitalización de cantidades vencidas, exigibles y no satisfechas; c) si el cliente o la entidad tienen la facultad de modificar la modalidad de pago establecida, así como las condiciones para su ejercicio; d) un ejemplo representativo de crédito con dos o más alternativas de financiación determinadas en función de la cuota mínima que pueda establecerse para el reembolso del crédito con arreglo al contrato. No obstante, si bien para ampliar el límite del crédito la entidad deberá actualizar previamente la información financiera de que disponga sobre el cliente y evaluar nuevamente su solvencia con arreglo a la nueva norma, lo cierto es que en su disposición transitoria única prevé que lo dispuesto en el nuevo artículo 33 ter, relativo a la comentada información precontractual, no será de aplicación para los contratos celebrados con anterioridad a la entrada en vigor de la norma ( 2 de enero de 2021). Con anterioridad a la mencionada norma encontramos una ausencia de regulación específica sobre el contenido de la información precontractual y contractual que debe suministrar el predisponente al consumidor en esta modalidad tan particular de crédito al consumo, contando tan solo con el marco general definido por la LCCC/2011 en sus artículos 10 y 16. Por tanto, en este epígrafe se pretende hacer una aportación para la defensa del consumidor frente a la abusividad por falta de transparencia de las cláusulas de los contratos de crédito revolving que se celebraron con anterioridad a la entrada en

17 A propósito de este tema AGÜERO ORTIZ, A.: Cuestiones sobre los límites a las cuotas y al sobreendeudamiento en créditos revolving de la orden ETD/699/2020. Publicaciones Jurídicas del Centro de Estudios de Consumo. Madrid, 2020.2 Disponible en: http://centrodeestudiosdeconsumo.com/images/Cuestiones sobre los limites a las cuotas y al sobre endeudamiento en creditos revolving.pdf 
vigor de la mencionada Orden 699/2020, considerando la mencionada ausencia de regulación específica hasta entonces, así como el hecho de que el Tribunal Supremo no se ha pronunciado aún sobre la proyección del control de transparencia en este sector de la contratación seriada.

En la práctica procesal se observa aún con demasiada frecuencia un control de transparencia incompleto, desarrollado únicamente desde la óptica de la claridad gramatical y no desde el ámbito de la comprensibilidad material. A modo de ejemplo, la sentencia no 339/2020 de 28 de octubre de la Sección Segunda de la Audiencia Provincial de Sevilla (SAP SE 1178:2020) considera que la cláusula de intereses es clara y supera el control de transparencia porque la misma dice literalmente que la Tasa Anual Equivalente de la tarjeta es del 23,9\% calculada con arreglo a la fórmula del Banco de España, información que permite al consumidor conocer el coste del contrato. En la misma línea, la Sección Octava de la Audiencia Provincial de Sevilla, en sentencia no 267/2019 de 16 de octubre (SAP SE 1245:2019) considera que las cláusulas de intereses remuneratorios y comisiones superan el doble control de transparencia, pues su redacción parece clara $y$, en todo caso, recoge tanto la TAE como el Tipo de Interés Nominal en la hoja de solicitud del crédito, la cual se encuentra firmada por el demandado e incluso con identificación y cuenta bancaria de cargo o condiciones personales restantes.

Vaya por delante que no es posible emitir un juicio de valor relativo a si determinadas cláusulas contractuales son transparentes o no sin estudiar el contenido de la documental probatoria en cada caso concreto, pero a priori la argumentación de las dos sentencias citadas se aparta de los parámetros del control de transparencia fijados por el TJUE y el TS, al considerar únicamente si su redacción es legible y si en el documento se recogen la TAE y el TIN, aspectos que permiten superar el control de incorporación pero, por sí solos, no el doble control de transparencia ${ }^{18}$. Debe recordarse que las condiciones generales en la contratación con consumidores deben estar redactadas de manera legible, por supuesto, pero no basta con eso, sino que además la información proporcionada al consumidor debe ser suficiente para que éste conozca o pueda conocer tanto la carga económica como jurídica que el contrato supone, es decir, por un lado la onerosidad y sacrificio patrimonial realizado a cambio de la prestación económica que se quiere obtener, y por otro lado la definición clara de su posición jurídica en los presupuestos típicos que configuran el contrato celebrado y en la distribución de los riesgos de desarrollo del mismo. Así, asistimos a una valoración incompleta de la transparencia de las cláusulas que configuran el sistema de crédito revolving por parte del órgano judicial, cuando éste se limita a examinar si el contrato está redactado de manera legible, con un tamaño y contraste suficiente, si indica el TIN y la TAE, sin entrar a valorar nada más, ya que estos parámetros no resultan suficientes por sí solos en términos de información clara y

${ }^{18}$ En esa línea, si bien respecto a la cláusula suelo, se pronunciaba la STS, Sala de lo Civil, no 486/2018 de 12 de septiembre (RJ 2018, 3993). 
comprensible al consumidor sobre la carga económica y jurídica de la operación ${ }^{19}$. En mi opinión, la transparencia material, y no exclusivamente gramatical, exige que el predisponente proporcione al consumidor una información más amplia, sobre aspectos como las consecuencias de aplazar la devolución del capital dispuesto, el significado de la capitalización de los intereses que se devengan periódicamente, las consecuencias de elegir una cuota mensual de bajo importe (particularmente el riesgo de que el plazo de amortización se prolongue de manera indefinida, con el incremento del coste total del crédito que ello conlleva), así como advertencias sobre la posibilidad de que la cuota mensual elegida no sea suficiente para amortizar capital o incluso para absorber los intereses devengados, pese a que algunos de los mencionados aspectos no aparezcan expresamente contemplados en el contenido de la información precontractual y contractual que se establece en los artículos 10 y 16 de la LCCC/2011.

Una información transparente exige la explicación sistemática y global al consumidor del sistema de crédito que se le ofrece, explicación que resulta insuficiente e incluso engañosa cuando se publicita el sistema como la posibilidad de devolver el crédito en cómodos plazos, ocultando que la devolución de capitales moderadamente elevados con cuotas mensuales de bajo importe convertirán al consumidor en un deudor cautivo. Así pues, el defecto de transparencia provoca subrepticiamente una alteración, no del equilibrio objetivo de precio y prestación sino del equilibrio subjetivo, es decir tal como se lo pudo representar el consumidor en atención a las circunstancias concurrentes en la contratación.

Cabe preguntarse si la cláusula relativa a los intereses remuneratorios de un contrato de tarjeta de crédito, en caso de no ser transparente será en todo caso abusiva. La STS, Sala de lo Civil, no 595/2020 de 12 de noviembre (STS 3613:2020) aborda esta cuestión a propósito de las cláusulas relativas al IRPH de los préstamos hipotecarios, sosteniendo que el hecho de que la cláusula no sea transparente no implica necesariamente que sea abusiva ${ }^{20}$ y que los controles de transparencia y abusividad son diferentes, siendo el primero presupuesto o antecedente del segundo. No se discute que los controles de transparencia y abusividad son diferentes y que los parámetros para determinar la abusividad de una condición general de la contratación son el desequilibrio importante en los derechos y obligaciones de las partes, la contravención de las exigencias de la buena fe y el perjuicio al consumidor, ahora bien, en un artículo de opinión comentando dicha sentencia ${ }^{21}$, he argumentado que el Tribunal Supremo se equivoca al proyectar el examen de abusividad en el caso de las cláusulas IRPH, considerando que éstas se refieren al elemento esencial del

${ }_{19}$ A propósito del control de transparencia en el sector de las tarjetas revolving ha escrito BERROCAL LANZAROT, A.: Tarjetas y créditos revolving o rotativos: la usura y el control de transparencia. Dykinson. Madrid, 2020. Página 135 y siguientes.

${ }^{20}$ Al contrario de cuanto tiene declarado reiteradamente respecto a las cláusulas suelo: STS de 8 de septiembre de 2014; STS, Sala de lo Civil, no 705/2015 de 23 de diciembre (STS 5618:2015); STS de 24 de noviembre de 2017; STS de 12 de septiembre de 2018; STS, Sala de lo Civil, no 286/2020 de 11 de junio (RJ 2020, 1806).

${ }^{21}$ BURRERO DEL CASTILLO, D.: El juicio de abusividad subsiguiente al control de transparencia de las cláusulas IRPH. La Toga Digital. 23 de febrero de 2021. Disponible en: https://www.revistalatoga.es/eljuicio-de-abusividad-subsiguiente-al-control-de-transparencia-de-las-clausulas-irph/ 
contrato, su precio, y que según el criterio del propio TS (compartido por el Gobierno de España) en el Reino de España sí se transpuso el artículo 4.2 de la Directiva 93/13, de modo que quedaría vedado al juzgador el control de contenido ${ }^{22}$. Siendo así, en un Estado Miembro que haya transpuesto el artículo 4.2 de la Directiva 93/13 no puede valorarse la abusividad atendiendo a cuál tipo de interés es más alto o más bajo, sino sobre la base de un perjuicio provocado directamente por la sustracción de información relevante al consumidor a efectos de decidir si se adhería o no al contrato con cláusulas predispuestas, es decir el examen de abusividad de una cláusula relativa a los intereses remuneratorios de un contrato de préstamo o de crédito al consumo sólo podría efectuarse bajo el prisma de la transparencia. En palabras del Magistrado Arroyo Fiestas en su Voto Particular a dicha sentencia, el perjuicio al consumidor consiste en el presente caso en la alteración sorpresiva del acuerdo económico que se creía haber alcanzado, a partir de la información precontractual, que resultó incompleta, privándole de la posibilidad de comparar las ofertas del mercado; precisamente es la falta de información lo que genera un desequilibrio de carácter subjetivo que contraviene las exigencias de la buena fe y perjudica gravemente al consumidor, lo cual conduce a la determinación del carácter abusivo de la cláusula. En la jurisprudencia del TS encontramos por tanto dos casuísticas similares, cláusulas suelo y cláusulas IRPH, a las que da soluciones contrapuestas en lo relativo a la conexión entre el control de transparencia y el control de abusividad. Por lo que respecta al sector de contratación seriada que nos ocupa, tarjetas de crédito revolving, el Tribunal Supremo no ha tenido ocasión aún de pronunciarse (más allá del brevísimo comentario que hace obiter dicta en la STS de 4 de marzo de 2020 para decirnos que la cláusula de intereses está sujeta a control de transparencia). En mi opinión, la falta de transparencia que afecta a la cláusula de intereses priva al consumidor de la posibilidad de valorar y comparar las diferentes ofertas del mercado y, precisamente por ello, comporta un desequilibrio real, cierto e importante, contrario a la buena fe y perjudicial, que deriva en su carácter abusivo.

Llegados a este punto, procede analizar cuáles son las consecuencias de la declaración de nulidad de las cláusulas abusivas. El artículo 83 TRLGDCU en su actual redacción es contundente al respecto: "Las cláusulas abusivas serán nulas de pleno derecho y se tendrán por no puestas. A estos efectos, el Juez, previa audiencia de las partes, declarará la nulidad de las cláusulas abusivas incluidas en el contrato, el cual, no obstante, seguirá siendo obligatorio para las partes en los mismos términos,

\footnotetext{
22 Pese a la transposición del art. 4.2 de la Directiva 93/13, conviene recordar el art. 8 de la misma ya permitía desde su origen a los Estados Miembros ampliar el nivel de protección de los consumidores extendiendo el control de contenido al objeto principal del contrato. No obstante, la Directiva 2011/83/UE del Parlamento Europeo y del Consejo de 25 de octubre de 2011 sobre los derechos de los consumidores, por la que se modifican la Directiva 93/13/CEE del Consejo y la Directiva 1999/44/CE del Parlamento Europeo y del Consejo y se derogan la Directiva 85/577/CEE del Consejo y la Directiva 97/7/CE del Parlamento Europeo y del Consejo (DOUE de 22/11/2011), introdujo un nuevo artículo 8 bis en la Directiva 93/13, por el cual contempla expresamente la posibilidad de que los Estados Miembros extiendan la evaluación del carácter abusivo a la adecuación del precio. En mi opinión, sería conveniente que el legislador español haga uso de la facultad que le otorga la Directiva 93/13 en su art. 8 bis con el fin de garantizar al consumidor un nivel más elevado de protección.
} 
siempre que pueda subsistir sin dichas cláusulas (...) Las condiciones incorporadas de modo no transparente en los contratos en perjuicio de los consumidores serán nulas de pleno derecho." El último inciso del precepto, relativo a la nulidad absoluta de las cláusulas no transparentes, ha sido incorporado por la disposición final octava de la Ley $5 / 2019$, de 15 de marzo, reguladora de los contratos de crédito inmobiliario (BOE no 65 de 16/03/2019), en vigor desde el 16 de junio de 2019.

De lo establecido en él se extrae que es una nulidad absoluta o de pleno derecho, pero también que no provoca, al menos en principio, la ineficacia del contrato en su totalidad sino sólo de las cláusulas abusivas, siempre que el contrato pueda subsistir sin dichas cláusulas ${ }^{23}$. Se plantean dos problemas a propósito de las consecuencias de la declaración de nulidad: a) el alcance de la misma si es formulada por el demandado por la vía de la excepción en la oposición al procedimiento monitorio y, en su caso, en la contestación a la demanda de juicio ordinario y b) si la abusividad por falta de transparencia afecta a la cláusula de intereses remuneratorios, ¿se considera ésta elemento esencial del contrato en el sentido de que éste no podrá subsistir sin dicha cláusula?

Respecto a la primera cuestión, no plantea dudas que el demandado puede plantear la nulidad de determinadas cláusulas contractuales en razón de su carácter abusivo por la vía de la excepción. Dicha alegación tiene una naturaleza defensiva y su función está limitada a la búsqueda de la desestimación de la demanda, es decir sólo podrá tener un alcance enervatorio. Ello significa que en caso de ser estimada la excepción de nulidad de las cláusulas abusivas, la consecuencia será la supresión de las mismas del contrato, teniéndolas por no puestas y estando prohibida, con carácter general, la moderación o integración de su contenido ${ }^{24}$. La nulidad comporta la inaplicación de las cláusulas abusivas en el sentido de recalcular el saldo reclamado y no condenar al demandado a pagar a la actora ningún concepto que encuentre fundamento en la aplicación de dichas cláusulas. Sin embargo, dada su naturaleza de excepción no podrá conducir a la condena del demandante a restituir al demandado el saldo que pudiera resultar a su favor como consecuencia de la anulación e inaplicación de la cláusula, pues para ello sería necesario que el demandado formulara reconvención.

Respecto a la segunda cuestión, en mi opinión el interés remuneratorio es un elemento accesorio y no esencial del contrato de préstamo, ya que éste aparece configurado como naturalmente gratuito en nuestro ordenamiento jurídico (aunque en la práctica la gratuidad sea absolutamente excepcional), es decir el préstamo no devenga intereses salvo que se haya estipulado expresamente ${ }^{25}$, así se deduce tanto

\footnotetext{
${ }^{23}$ A propósito de ello escribió CARRASCO PERERA, A., en: Las cláusulas abusivas se eliminan sin más: no cabe reducirlas, moderarlas ni modificarlas. Centro de Estudios de Consumo. Disponible en: http://centrodeestudiosdeconsumo.com/images/CONDICIONES GENERALES DE LA CONTRATACION/LA S CL\%C3\%81USULAS ABUSIVAS SE ELIMINAN SIN M\%C3\%81S.pdf

${ }^{24}$ BALLUGERA GÓMEZ, C.: Integración de cláusulas declaradas nulas por abusivas: visión general. Diario La Ley, No 8330, Sección Doctrina, 11 de Junio de 2014, Año XXXV, Editorial LA LEY, pág. 1.

${ }^{25}$ En esta línea, BALLUGERA GÓMEZ, C.: La Sentencia del Tribunal de Luxemburgo reactiva la lucha contra las cláusulas abusivas (I). Comentario a la STJUE de 14 de Marzo de 2013. Diario La Ley núm. 8088, Sección Doctrina, 22 de Mayo de 2013, Año XXXIV, Editorial LA LEY, pág. 6.
} 
del artículo 1740 del Código Civil (Real Decreto de 24 de julio de 1889 por el que se publica el Código Civil, «Gaceta de Madrid» núm. 206, de 25 de julio de 1889) como del artículo 314 del Código de Comercio (Real Decreto de 22 de agosto de 1885 por el que se publica el Código de Comercio, «Gaceta de Madrid» núm. 289, de 16 de octubre de 1885). Sin embargo, pese a que es una posición que personalmente no comparto, según reiterada jurisprudencia del Tribunal Supremo la cláusula de interés remuneratorio regula el elemento esencial del contrato de préstamo (precio o remuneración $)^{26}$, por lo que en orden a valorar las consecuencias de la declaración de nulidad, necesariamente debemos atenernos a dicha caracterización de la cláusula de intereses como elemento esencial, y ello implica que el contrato no podrá subsistir con la supresión de la cláusula. La imposibilidad de que el contrato subsista una vez suprimida la abusiva cláusula de intereses conduce a dos alternativas: la integración del contrato con normas supletorias de Derecho nacional, si las hubiera, posibilitando la subsistencia del mismo, por un lado, o bien la nulidad contractual con los efectos del artículo 1303 del Código Civil, es decir debiendo restituir el prestatario el capital recibido y el prestamista todos los conceptos percibidos distintos del capital que se le prestó.

Conviene acudir a la jurisprudencia del TJUE sobre dicha cuestión. En primer lugar, la STJUE, Gran Sala, de 26/03/2019, asuntos acumulados C-70/17 y C-179/17 (ECLI:EU:C:2019:250), en la que se analizan los efectos de la declaración del carácter abusivo de una cláusula (en aquel caso concreto, la de vencimiento anticipado de los préstamos hipotecarios) y las facultades del juez nacional de integrar el contrato con una disposición supletoria de Derecho nacional. De ella se extraen las siguientes conclusiones:

En primer lugar, cuando el juez nacional declara una cláusula abusiva, debe anularla y tenerla por no puesta, de modo que no despliegue ningún efecto perjudicial frente al consumidor, ya que la modificación del contenido de una cláusula abusiva es contraria al artículo 6.1 de la Directiva 93/13. Si el juez nacional tuviera la facultad de modificar el contenido de una cláusula abusiva, dicha facultad contribuiría a eliminar el efecto disuasorio que ejerce sobre los profesionales el hecho de que, pura y simplemente, tales cláusulas no se apliquen frente a los consumidores, en la medida en que los profesionales podrían verse tentados a utilizar cláusulas abusivas al saber que, aun cuando llegara a declararse su nulidad, el contrato podría ser integrado por el juez nacional en lo que fuera necesario, garantizando de este modo los intereses de los predisponentes y no de los consumidores.

En segundo lugar, el juez nacional puede, en casos excepcionales sin vulnerar la Directiva 93/13, suprimir una cláusula abusiva y sustituirla por una disposición supletoria de Derecho nacional, cuando la declaración de nulidad de una cláusula obligue al juez a anular el contrato entero, dejando expuesto al consumidor a consecuencias especialmente perjudiciales que representen para éste una penalización. Hay que insistir en que dicha facultad integradora es excepcional y sólo

${ }^{26}$ Entre otras, la citada STS de 14 de diciembre de 2017. 
se justifica por la consecución del objetivo de reemplazar el equilibrio formal del contrato por un equilibrio material o real que pueda restablecer la igualdad entre las partes. Si la nulidad de una cláusula provoca inevitablemente la nulidad del contrato en su totalidad y ello supone una penalización para el consumidor, está justificado que el juez nacional ejerza su facultad integradora ${ }^{27}$. Pero si el contrato puede subsistir sin la existencia de la cláusula abusiva, no procederá dicha integración.

En tercer lugar, incumbe al juez nacional comprobar con arreglo a las normas de Derecho interno y adoptando un enfoque objetivo, si la supresión de la cláusula provocará la nulidad del contrato entero $y$, en tal caso, si esto supondrá una penalización para el consumidor. Si llega a dicha conclusión, estaría justificado el ejercicio de la facultad integradora. Sin embargo, si el juez nacional llega a la conclusión de que el contrato puede subsistir sin la cláusula abusiva, debe anularla y tenerla por no puesta, sin efectuar integración alguna del contenido contractual.

Partiendo de la base de que el Tribunal Supremo ha declarado reiteradamente que la cláusula de intereses remuneratorios es un elemento esencial del contrato de préstamo y que, por tanto, anulada ésta tendrá que ser anulado el contrato en su totalidad, se plantea la cuestión de si la integración del contrato con lo establecido en normas supletorias de nuestro Ordenamiento jurídico interno, cuando el juez considere que las consecuencias de la nulidad total del contrato resultan perjudiciales para el consumidor, es una solución automática o, por el contrario, debe darse audiencia al consumidor antes de decidir. Veamos lo que dice la STJUE, Sala Tercera, de 03/10/2019, asunto C-260/18 (ECLI:EU:C:2019:819).

Según se expresa en dicha sentencia, para valorar si la anulación del contrato en su totalidad expone al consumidor a una situación perjudicial o no, deben tenerse en cuenta sus intereses reales y actuales, no sus intereses en las circunstancias existentes al momento de la celebración del contrato (párrafo 51). El juez no está obligado a excluir la aplicación de la cláusula abusiva en cuestión si el consumidor, tras haber sido informado por dicho juez, manifiesta su intención de no invocar el carácter abusivo y no vinculante de tal cláusula, otorgando así un consentimiento libre e informado a esa cláusula (párrafo 53), pues la Directiva 93/13 no llega hasta el extremo de hacer obligatorio el sistema de protección contra la utilización de cláusulas abusivas por los profesionales que ha instaurado en beneficio de los consumidores (párrafo 54). De manera análoga, el consumidor también tiene el derecho de oponerse a ser, en aplicación de ese mismo sistema, protegido de las consecuencias perjudiciales provocadas por la anulación del contrato en su totalidad

\footnotetext{
27 La integración de los elementos esenciales del contrato es una opción admitida desde la STJUE de 30 de abril de 2014, siempre que sea en favor del consumidor adherente porque la nulidad del contrato en su totalidad le exponga a consecuencias perjudiciales. Sobre este tema escribió BALLUGERA GÓMEZ, C.: Integración de cláusulas abusivas sobre elementos esenciales en beneficio del deudor y no del banco. La STJUE de 30 de Abril de 2014. Diario La Ley, N.o 8383, Sección Tribuna, 23 de Septiembre de 2014, Año XXXV. Editorial LA LEY, pág. 5.
} 
cuando no desee invocar tal protección (párrafo 55), de modo que la voluntad expresada por el consumidor al respecto es determinante (párrafo 56).

A modo de síntesis de lo expuesto en el asunto que nos ocupa, si el juez declara abusiva la cláusula de intereses remuneratorios, considera que la misma constituye un elemento esencial del contrato, que éste no puede subsistir sin él y que la nulidad contractual expondrá al consumidor a consecuencias perjudiciales, deberá dar audiencia al consumidor, siendo determinante la voluntad expresada por éste. Incumbe al consumidor demandado consentir la integración contractual con normas supletorias de Derecho interno, si las hubiera, o bien manifestar su intención de no invocar el carácter abusivo y no vinculante de la cláusula; si no consintiera ninguna de las mencionadas alternativas, el juzgador deberá declarar la nulidad del contrato en su totalidad. A propósito de los efectos restitutorios que se derivan de la declaración de nulidad contractual, me remito al siguiente epígrafe.

\section{Problemas prácticos al aplicar los efectos restitutorios de la declaración de nulidad contractual por usura}

Algunos órganos judiciales de instancia, una vez declarada la nulidad del contrato por intereses usurarios, aplican erróneamente las consecuencias de la nulidad. Delimitaré el supuesto mediante un ejemplo, en aras a una mayor claridad expositiva. La entidad financiera demandante reclama un saldo de 4.500 Euros con el siguiente desglose: 3.750 Euros de principal, 600 Euros de intereses, 150 Euros de comisiones por reclamación de posiciones deudoras. La deuda reclamada se fundamenta en un contrato de tarjeta de crédito celebrado en el año 2008, los intereses remuneratorios son del $26,82 \%$ T.A.E., se estipula una comisión de reclamación de posiciones deudoras de 30 euros, que se devenga automáticamente por cada recibo impagado, así como la capitalización de intereses y comisiones impagados. El órgano judicial declara la nulidad del contrato por usura al considerar, previa comparación con el interés medio de los créditos al consumo el mes y año de celebración del contrato, que el interés estipulado es notablemente superior al interés normal del dinero y desproporcionado con las circunstancias del caso, pero a la hora de aplicar las consecuencias de la nulidad se limita a descontar del saldo reclamado las partidas de intereses y comisiones, condenando al demandado a pagar el principal de 3.750 Euros. En mi opinión, en un caso concreto como el indicado, el órgano judicial estaría incurriendo en una infracción de lo establecido en el artículo 3 de la Ley de represión de la usura y en el artículo 1303 del Código Civil, por las razones que a continuación expondré.

Debe tenerse en cuenta que la partida de intereses del saldo recoge únicamente los intereses devengados e impagados que son objeto de reclamación, mientras que la partida de principal aportada por la actora refleja un cálculo de cierta complejidad que merece ser examinado con cierta atención: capital prestado menos la parte de amortización de capital de las cuotas pagadas (en los casos de usura, la amortización de capital representa una parte minoritaria de todo el montante pagado) más intereses y comisiones impagados que hayan podido capitalizarse. Este matiz es de 
suma importancia, pues la declaración de nulidad del contrato exige considerar, por un lado, el capital prestado o dispuesto y, por otro lado, las cantidades pagadas por todos los conceptos, es decir una correcta aplicación de los efectos restitutorios requiere, no sólo absolver al deudor de pagar las partidas de intereses y comisiones devengadas e impagadas que hayan sido objeto de reclamación, sino recalcular el saldo deduciendo del capital prestado las cantidades pagadas por todos los conceptos.

\section{Conclusiones}

$\left.1^{\circ}\right)$ En el supuesto de una reclamación de saldo derivado del uso de una tarjeta de crédito revolving, los arts. 812 y 815 LEC exigen para la admisión a trámite del monitorio la aportación tanto del contrato como del extracto de operaciones, no bastando un certificado de saldo por sí solo.

$\left.2^{\circ}\right)$ Las cláusulas abusivas son susceptibles de control de oficio en cualquier momento del procedimiento, siempre que éste no haya finalizado, el órgano judicial disponga de los elementos de hecho y de Derecho necesarios y no se haya emitido un pronunciamiento sobre la cláusula en cuestión mediante resolución firme con fuerza de cosa juzgada. A su vez, la nulidad contractual derivada de los intereses usurarios también es apreciable de oficio, aunque no haya sido alegada o se haya alegado con deficiencias de carácter formal por la parte, toda vez que en los casos de usura nos encontramos ante pactos manifiestamente ilegales, contrarios a la moral y al orden público.

$3^{\circ}$ ) La nulidad absoluta del contrato de tarjeta de crédito ocasionada por la estipulación de intereses usurarios puede alegarse por la vía de la excepción, figura llamada excepción reconvencional por la doctrina, tanto en la contestación a la demanda del juicio ordinario, según dispone expresamente el artículo 408.2 LEC, como en la contestación a la demanda del juicio verbal y en la oposición al monitorio, por analogía. Los principios de congruencia y exhaustividad exigen que la sentencia que se dicte en el proceso declarativo correspondiente se pronuncie sobre dicho extremo.

40) El control de transparencia en este sector de contratación seriada exige analizar no sólo si el contrato está redactado de manera legible y si indica el TIN y la TAE, sino también si el predisponente ha proporcionado una información materialmente comprensible para el consumidor medio, normalmente informado y razonablemente atento y perspicaz, sobre la carga económica y jurídica de la operación, exigencia que, de acuerdo con los requisitos de información precontractual y contractual establecidos en los artículos 10 y 16 de la LCCC/2011, no se satisface con la mera indicación del TIN y la TAE. La nueva Orden 699/2020 contempla expresamente, para los contratos celebrados a partir de la fecha de su entrada en vigor, que el predisponente debe informar al consumidor previamente a la celebración del contrato sobre la modalidad de pago revolving, la capitalización de cantidades 
vencidas, exigibles y no satisfechas, la posible facultad de modificar la modalidad de pago establecida, así como las condiciones para su ejercicio, y un ejemplo representativo de crédito con dos o más alternativas de financiación determinadas en función de la cuota mínima que pueda establecerse para el reembolso del crédito con arreglo al contrato. La falta de transparencia que afecta a la cláusula de intereses remuneratorios, dado su carácter de objeto principal del contrato, priva al consumidor de la posibilidad de valorar y comparar las diferentes ofertas del mercado y, precisamente por ello, comporta un desequilibrio real, cierto e importante, contrario a la buena fe y perjudicial, que deriva en el carácter abusivo de la cláusula.

La consecuencia de que una cláusula sea declarada abusiva es la nulidad absoluta de la misma. Si la nulidad de la cláusula abusiva fue alegada por la vía de la excepción, en caso de ser estimada ésta la consecuencia será la supresión de la misma del contrato, la inaplicación de la misma en el sentido de recalcular el saldo reclamado y no condenar al demandado a pagar a la actora ningún concepto que encuentre fundamento en la aplicación de la cláusula abusiva. Sin embargo, dada su naturaleza de excepción no podrá conducir a la condena del demandante a restituir al demandado el saldo que pudiera resultar a su favor como consecuencia de la anulación e inaplicación de la cláusula, pues para ello sería necesario que el demandado formulara reconvención. Si el juez llega a la conclusión de que la cláusula abusiva afectada por la nulidad es un elemento esencial, que la eliminación de la cláusula provocará la nulidad total del contrato y ello puede resultar perjudicial para el consumidor, deberá dar audiencia a éste sobre la posibilidad de integrar la laguna contractual con lo establecido en una norma supletoria de Derecho nacional, si la hubiera, o bien de mantener la validez de la cláusula abusiva previa emisión de un consentimiento libre e informado, advirtiéndole que de no consentir ninguna de las mencionadas alternativas ello provocará la nulidad absoluta del contrato en su totalidad, con las consecuencias del artículo 1303 CC.

50) El artículo 3 de la Ley de represión de la usura y el artículo 1303 del Código Civil exigen, una vez estimada la excepción reconvencional de nulidad del contrato por intereses usurarios, no sólo absolver al deudor de pagar las partidas de intereses y comisiones devengadas e impagadas que hayan sido objeto de reclamación, sino también recalcular el saldo deduciendo del capital prestado las cantidades pagadas por todos los conceptos.

\section{Referencias y citas}

Citas bibliográficas:

AGÜERO ORTIZ, A.: El TJUE declara que los jueces solo han de examinar de oficio la abusividad de las cláusulas vinculadas al objeto del litigio. Publicaciones Jurídicas Centro de Estudios de Consumo. Madrid, 15 de abril de 2020. Disponible 
en:http://centrodeestudiosdeconsumo.com/images/EI TJUE declara que los j ueces solo han de examinar de oficio la abusividad de las clausulas vincul adas al objeto del litigio.pdf

AGÜERO ORTIZ, A.: Cuestiones sobre los límites a las cuotas y al sobreendeudamiento en créditos revolving de la orden ETD/699/2020. Publicaciones Jurídicas del Centro de Estudios de Consumo. Madrid, 7 de octubre de 2020.2 Disponible en: http://centrodeestudiosdeconsumo.com/images/Cuestiones sobre los limites a las cuotas $y$ al sobreendeudamiento en creditos revolving.pdf

AGÜERO ORTIZ, A.: No realizar el control de abusividad vulnera el derecho a la tutela judicial efectiva. Publicaciones Jurídicas del Centro de Estudios de Consumo. Madrid, 16 de junio de 2021. Disponible en: http://centrodeestudiosdeconsumo.com/images/No realizar el control de abu sividad vulnera el derecho a la tutela judicial efectiva.pdf

ALFARO ÁGUILA-REAL, J.: Las condiciones generales de la contratación. Civitas. Madrid, 1991.

ARSUAGA CORTÁZAR, J.: Artículo 408.2: Alegación de nulidad del negocio jurídico en que se funda la demanda en Marín Castán, F. (Director), Comentarios a la Ley de Enjuiciamiento Civil. Tirant Lo Blanch. Valencia, 2015. Página 1779 y siguientes.

BALLUGERA GÓMEZ, C.: La Sentencia del Tribunal de Luxemburgo reactiva la lucha contra las cláusulas abusivas (I). Comentario a la STJUE de 14 de Marzo de 2013. Diario La Ley núm. 8088, Sección Doctrina. Editorial LA LEY, 22 de Mayo de 2013.

BALLUGERA GÓMEZ, C.: Integración de cláusulas declaradas nulas por abusivas: visión general. Diario La Ley, núm. 8330, Sección Doctrina. Editorial LA LEY, 11 de Junio de 2014.

BALLUGERA GÓMEZ, C.: Integración de cláusulas abusivas sobre elementos esenciales en beneficio del deudor y no del banco. La STJUE de 30 de Abril de 2014. Diario La Ley, núm. 8383, Sección Tribuna. Editorial LA LEY, 23 de Septiembre de 2014.

BERROCAL LANZAROT, A.: Tarjetas y créditos revolving o rotativos: la usura y el control de transparencia. Dykinson. Madrid, 2020. Página 135 y siguientes.

BRUÑÉN BARBERÁ, F.: Artículo 218: Principio de Congruencia en Marín Castán, F. (Director), Comentarios a la Ley de Enjuiciamiento Civil. Tirant Lo Blanch. Valencia, 2015. Página 1016 y siguientes. 
BURRERO DEL CASTILLO, D.: El juicio de abusividad subsiguiente al control de transparencia de las cláusulas IRPH. La Toga Digital. Sevilla, 23 de febrero de 2021. Disponible en: https://www.revistalatoga.es/el-juicio-de-abusividadsubsiguiente-al-control-de-transparencia-de-las-clausulas-irph/

CARRASCO PERERA, A., en: Las cláusulas abusivas se eliminan sin más: no cabe reducirlas, moderarlas ni modificarlas. Condiciones generales de la contratación y cláusulas abusivas. Centro de Estudios de Consumo. Junio de 2012. Disponible en:http://centrodeestudiosdeconsumo.com/images/CONDICIONES GENERALES DE LA CONTRATACION/LAS CL\%C3\%81USULAS ABUSIVAS SE ELIMINAN S IN M\%C3\%81S.pdf

GARCÍA DE LA ROSA, C.: Las excepciones reconvencionales y su régimen en el juicio verbal. Revista General de Derecho Procesal 35 (2015). Iustel. Madrid, 2015.

MORENO GARCÍA, L.: Las cláusulas abusivas: tratamiento sustantivo y procesal. Tirant Lo Blanch. Valencia, 2019. Página 525 y siguientes.

ORDUÑA MORENO, J.; SÁNCHEZ MARTÍN, C.; GUILLÉN CATALÁN, R.: Control de transparencia y contratación bancaria: régimen jurídico y doctrina jurisprudencial aplicable. Tirant Lo Blanch. Valencia, 2016.

TAFUR LÓPEZ DE LEMUS, J.: ¿Es necesario formular reconvención en la contestación a la demanda en el juicio verbal si se alega la nulidad de un contrato? (art.408 y 438.3 LEC). Sitio web El Derecho - Lefebvre, 29/05/2018. Disponible en: $\quad$ https://elderecho.com/es-necesario-formular-reconvencion-en-lacontestacion-a-la-demanda-en-el-juicio-verbal-si-se-alega-la-nulidad-de-uncontrato-art-408-y-438-3-lec

Jurisprudencia:

Tribunal de Justicia de la Unión Europea:

- STJUE, Sala Tercera, de 11/03/2020 (ECLI:EU:C:2020:188).

- STJUE, Sala Primera, de 14/06/2012 (ECLI:EU:C:2012:349).

- STJUE, Sala Primera, de 26/01/2017 (ECLI:EU:C:2017:60).

- STJUE, Sala Cuarta, de 30/04/2014 (ECLI:EU:C:2014:282).

- STJUE, Sala Cuarta, de 03/09/2015 (ECLI:EU:C:2015:538).

- STJUE, Sala Segunda, de 20/09/2017 (ECLI:EU:C:2017:703).

- STJUE, Gran Sala, de 03/03/2020 (ECLI:EU:C:2020:138).

- STJUE, Gran Sala, de 26/03/2019 (ECLI:EU:C:2019:250).

- STJUE, Sala Tercera, de 03/10/2019 (ECLI:EU:C:2019:819). 
Tribunal Constitucional:

- STC, Pleno, de 28/02/2019 (ECLI:ES:TC:2019:31).

- STC, Sala Segunda, de 06/10/2020 (ECLI:ES:TC:2020:140).

- STC, Sala Primera, de 15/02/2021 (ECLI:ES:TC:2021:24).

- STC, Sala Primera, de 10/05/2021 (ECLI:ES:TC:2021:102).

- STC, Pleno, de 05/05/1982 (ECLI:ES:TC:1982:20).

Tribunal Supremo:

- STS, Sala de lo Civil, de 20/06/1996 (TOL1.659.451).

- STS, Sala de lo Civil, de 25/11/2015 (STS 4810:2015).

- STS, Sala de lo Civil, de 04/03/2020 (STS 600:2020).

- STS, Sala de lo Civil, de 23/03/2018 (STS 1110:2018).

- STS, Sala de lo Civil, de 06/06/2013 (TOL3.853.518).

- STS, Sala de lo Civil, de 12/06/2013 (TOL3.834.289).

- STS, Sala de lo Civil, de 18/06/2012 (TOL2.652.597).

- STS, Sala de lo Civil, de 08/09/2014 (TOL4.529.142).

- STS, Sala de lo Civil, de 24/11/2017 (STS 4092:2017).

- STS, Sala de lo Civil, de 14/12/2017 (STS 4308:2017).

- STS, Sala de lo Civil, de 12/09/2018 (RJ 2018, 3993).

- STS, Sala de lo Civil, de 12/11/2020 (STS 3613:2020).

- STS, Sala de lo Civil, de 23/12/2015 (STS 5618:2015).

- STS, Sala de lo Civil, de 11/06/2020 (RJ 2020, 1806).

Audiencias Provinciales:

- AAP Sevilla, Sección Sexta, de 08/10/2020 (AAP SE 571:2020).

- AAP Sevilla, Sección Segunda, de 17/03/2021 (AAP SE 88:2021).

- AAP Barcelona, Sección 16a, de 20/05/2021 (AAP B 3633:2021).

- AAP Las Palmas, Sección Quinta, de 21/02/2020 (AAP GC 51:2020).

- AAP Girona, Sección Segunda, de 27/04/2018 (AAP GI 229:2018).

- AAP Valladolid, Sección Tercera, de 22/02/2021 (AAP VA 199:2021).

- SAP Sevilla, Sección Sexta, de 21/12/2020 (SAP SE 1383:2020).

- SAP Barcelona, Sección Cuarta, de 21/04/2021 (SAP B 4212:2021).

- SAP Badajoz, Sección Tercera, de 26/11/2020 (SAP BA 1434:2020).

- SAP Valencia, Sección Octava, de 31/03/2021 (SAP 1338:2021).

- SAP Sevilla, Sección Sexta, de 05/11/2020 (SAP SE 1068:2020).

- SAP Sevilla, Sección Segunda, de 28/10/2020 (SAP SE 1178:2020).

- SAP Sevilla, Sexta Octava, de 16/10/2019 (SAP SE 1245:2019). 